\title{
The Effectiveness of Value Clarification Technique Learning Model on Students' Learning Outcomes
}

\author{
Restu Yanuar Ula ${ }^{\text {* }}$, Sarkadi ${ }^{2}$, Aip Badrujaman ${ }^{3}$ \\ 1,2,3 Postgraduate Historical Education Study Program, State University of Jakarta, Jakarta, Indonesia \\ *Corresponding author: yanuarularestu@gmail.com
}

\begin{abstract}
Improving the quality of education is based on the formation of the quality of learning through teacher competence in managing the classroom. However, the problem is that the learning outcomes of history are still relatively low because the competence of teachers in applying the method is still monotonous. On the other hand, the VCT learning model can provide creative-critical power, foster positive attitudes, interests, and values in students in learning history. Therefore, this study aims to determine the effect of the Value Clarification Technique learning model on student learning outcomes of history. The research method used quantitative methods with a quasi-experimental design. The research design used was the NonEquivalent Pretest-Posttest Design. The population in this study was all students of grade XI. At the same time, the sampling technique is purposive sampling which is divided into two classes into the experimental group and the control group. The results of this study indicate that the VCT learning model affects student learning outcomes in history learning.
\end{abstract}

Keywords: VCT, Learning Outcomes

History:
Received : 26 October 2020
Revised : 1 November 2020
Accepted : 19 December 2020
Published : 25 April 2021

\section{Introduction}

The establishment of the quality of human resources becomes an essential factor in the advancement of education (Casinillo \& Aure, 2018). Human resources are very potential to play a significant role in realizing the life of an intelligent and creative nation to compete globally. This is a demand of the purpose of Indonesia's national standard of education, which is to educate the life of the nation. These demands make motivation and positive benchmarks in carrying out a good and competent learning process in the classroom (Khairunisa, 2017; Wijayanti, 2015). Therefore, the quality of learning will depend heavily on human resources such as teachers.

The competence of teachers as educators will be an important highlight in the implementation of learning and the process of educating the nation (Doležalová, 2015; Ramadhan \& Soenarto, 2015). A teacher expects that what is taught is acceptable and understandable to be a provision for his students in their daily lives. Therefore, learning in the education unit is organized interactively, inspiring, fun, challenging, motivating learners to participate actively, and providing sufficient space for students' physical, interest, mental and psychological development (Mannan \& Sopyan, 2005; Rai, 2013). In the 2013 curriculum, it is obvious how learning should focus on students' activeness to think and argue and limit the role of teachers excessively in delivering materials. Such learning should occur in all subjects at the high school level, including History subjects. 
History is a branch of science that systematically examines the development of change and dynamics of people's lives with all aspects of their lives that occurred in the past (Sardiman, 2015; Suryani et al., 2013). Therefore, learning history in schools should be encouraged to create situations that can develop historical awareness (Sayono, 2013; Ulhaq et al., 2017). So the material in the study of history is not only memorized material in the form of dates, years, or figures but should include many benefits from every element of human life (Munawar \& Suryadi, 2019). That way, history learning should be able to inspire students to be interested in learning it. Meanwhile, in the 2013 curriculum, history gets more portions of compulsory subjects and concentration for high schools / vocational schools, both in terms of time allocation and subject matter. This is an opportunity for history teachers to explore history learning to learners to achieve the purpose of history learning.

The problem that occurs when learning history that some students still consider boring is that it seems to "memorize" and does not benefit. After all, the study is passed (Aman, 2013; Jumardi, 2017). Conventional methods such as lectures will be very influential such as decreased student contingency, students' interest and motivation towards their teachers or subjects, and increasing student inactivity during the learning process. The dominant role of teachers and only as objects of control in conventional learning makes historical learning less effective (Siregar et al., 2019).

Therefore, a history teacher must create learning to activate the student and attract students to like the history lesson. Interestingly, historical science becomes an important subject because it relates to the internalization of character values, morals, and attitudes taken from past events. History teachers teach students how they understand historical events and how history teachers foster student character education, including in terms of working together to face global and social challenges. Thus, the teacher's learning model influences the success of the historical learning process. Then there are various models of learning values that can be used to develop the attitudes and character of students, one of which is the VCT Value Clarification Technique.

Value Clarification Technique (VCT) is a way of instilling and digging or expressing specific values of students (Sutaryanto, 2016). Meanwhile, a technique of clarifying value (Value Clarification Technique), often abbreviated as VCT, can be interpreted as teaching techniques to help students in finding and determining a value that is considered good in dealing with an issue through the process of analyzing existing values and embedded in students (Sanjaya., 2017). Value Clarification Technique (VCT) model is very appropriate for historical learning because history learning is tasked with instilling character values through its materials. In addition, the VCT model can lead students to have the skills or ability to determine the good life values following their life goals and internalize them so that values become guidelines in acting or acting. Therefore, the use of VCT learning models is expected to contribute to the development of the quality of historical learning. In addition, this research can also be helpful for teachers in designing and implementing active, innovative, creative, and moral history learning.

Concerning research on the application of VCT learning models, several studies have been done, such as Mosconi \& Emmett (2003), in their research concluded that value clarification learning is effective to help in understanding values, future careers, and ways of achieving success. In addition, research from Byford et al. (2009) concluded that the use of value clarification discussion techniques for social science learning proved to be a valuable method to increase student awareness in society and help students to develop and facilitate understanding of specific issues, improve critical thinking skills, and improve interpersonal skills. Furthermore, Wijayanti (2015) conducted research that showed that learning by applying the VCT learning model can bring about positive behavior of learners such as aspects of religious values and devout worship, tolerance towards others, discipline, concern 
for friends, deliberation, and responsibility in completing tasks on time both individuals and groups. There is also research from Khairunisa (2017) that proves that through the VCT learning model, it explains that students become more understanding about social problems and social values and make social science learning more meaningful and instill the values of social care logically. So, if it is concluded from the results of previous research that the VCT model can be a suitable alternative for planting students' character through learning activities, especially historical learning, and can foster positive attitudes and social care that can be applied in daily life and students can internalize positive values in themselves democratically.

This study aims to determine the difference in learning outcomes between groups of students who learned using VCT learning models and groups of students who learned using conventional learning.

\section{Materials and Methods}

The research method used in this research is quantitative research methods with a quasi-experimental design. While the research design used in this experimental research is the Non-equivalent Control Group Design (Reichardt \& Mark, 2015). In this design, both the experimental and control groups are compared, even though these groups are selected and placed without being randomized.

The research was conducted at SMA Negeri 9 Bogor City in the odd semester period from August to September of the 2020/2021 school year. The population in this study were all students of class XI in SMA Negeri 9 Bogor City, totaling 320 students. Sampling in this study is based on the purposive sampling technique, namely, the sampling technique not based on random, regional, or strata, but on the existence of specific considerations in taking the sample or determining the sample for a specific purpose. Regarding the meaning of the sampling technique and indications of its use, purposive sampling is more appropriate when looking at the current emergency during the Covid 19 pandemic where schools have to study online. The division of two groups, namely the experimental class and the control class, was chosen without being random. Therefore, class XI IPA-3 was determined as the experimental group and class XI IPA-1 as the control group.

The implementation of this research consists of three stages: the preparation stage, the implementation stage, and the reporting stage. The preparation stage consists of designing learning tools and instruments for research, consulting learning tools and instruments with supervisors and experts, testing instruments used for research, conducting research, instrument analysis, and revising research instruments that have been done. At this stage of the meeting, four online meetings were held through the zoom application, google meet, and google form. In addition, three meetings were conducted to provide treatment and one meeting to provide posttest using the google form application. This online meeting is held only once a week according to the schedule determined by the school during the pandemic. The steps taken at this stage are to provide treatment of online-based VCT learning models in the experimental class and conventional learning in the control class, then hold a posttest in the experimental class and control class. Then at the reporting stage carried out is conducting data analysis followed by testing the hypothesis according to the data obtained and compiling a research report according to the data analysis.

In this study, there are two variables, namely the independent variable and the dependent variable. The online-based VCT learning model is the independent variable and historical effective learning outcomes as the dependent variable. The data collection method in this study is the test method, so the instrument used in this study is an objective testmultiple choice type. Students who answered correctly were given a score of 1, and students who answered incorrectly got 0 . After that, the preparation of a good instrument must be tested for validity, reliability testing, difficulty level testing, and test differentiation power 
test first. The content validity test was carried out by consulting two experts (judges) related to the effective history learning outcomes and calculating 1.00 very good categories. Based on the results of the test with a total of 39 tests, it was found that 2 tests were invalid and 37 items were valid, the reliability test of the test was 0.9079 with very high criteria, the test for the difference between the test results was 0.34 with good enough criteria and the level of difficulty of the test was the result. 0.68 with moderate criteria.

The data analysis used is descriptive statistical analysis and inferential statistics through t-test. Descriptive statistical analysis includes: mean, median, mode, variance, and standard deviation. Before testing for getting a conclusion, first, a normality test is carried out using the Chi-Square (x) test at a significance level of 5\% and degrees of freedom $\mathrm{db}=$ (k-1). Furthermore, the group variance homogeneity test was carried out using the $\mathrm{F}$ test at a significant level of 5\% with degrees of freedom for the numerator $n 1-1$ and degrees of freedom for the denominator $\mathrm{n} 2-1$. After the data is known to be normal and the variance is homogeneous, the hypothesis is tested using the independent sample t-test (not correlated). In this study, the t-test formula used to test the hypothesis is polled variance.

\section{Results and Discussion Results}

Data from this study was obtained from the posttest score of historical students' learning results due to the application of VCT learning models in the experimental and conventional learning groups in the control group. In the experimental group of 36 students, the highest score was 30, and the lowest score was 14. If described the score is mean $(\mathrm{M})=$ 24.36, median $(\mathrm{Md})=25.2$ mode $(\mathrm{Mo})=27$, variance $\left(\mathrm{s}^{2}\right)=20.91$, and standard deviation $(\mathrm{s})=4,57$. The data of the student learning test history of the experimental group is presented into polygon form as in Figure 1.

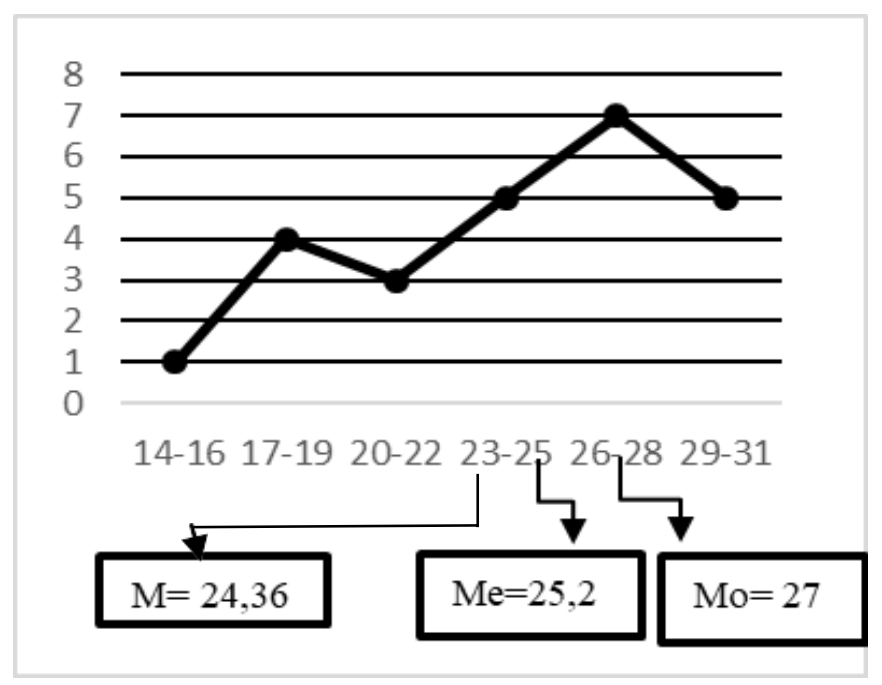

Figure 1. Polygon Curve Student Learning Outcomes History Experiment Group

Based on the polygon curve above, it is known that the mode is greater than the median and the median is greater than the mean $(\mathrm{Mo}>\mathrm{Md}>\mathrm{M})$, which is $27>25,2>24.36$, so the above curve is a negative squint curve. That means the score obtained is likely to be high. In comparison, the data of historical student learning results in the control group can be presented in polygon curves as in Figure 2. 


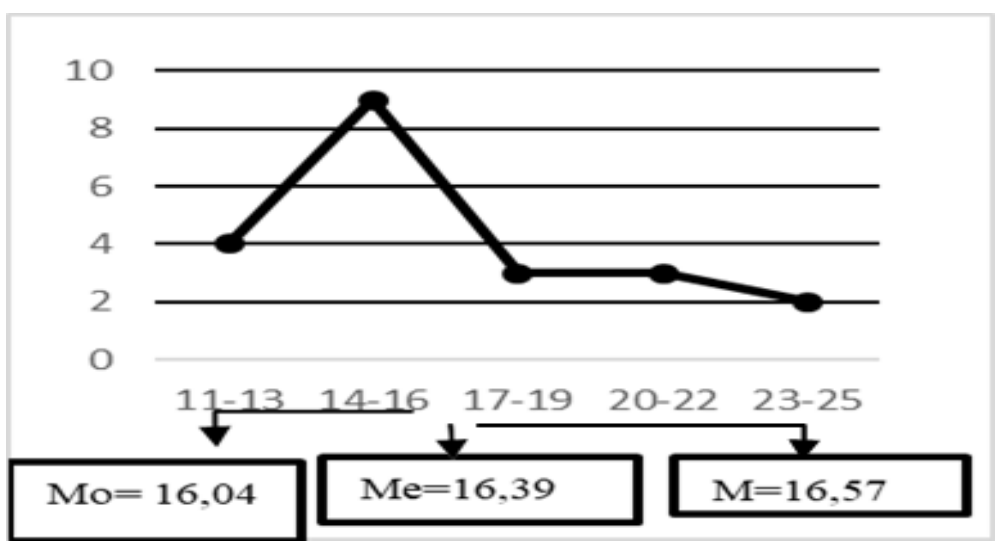

Figure 2. Polygon Curve Student Learning Outcomes History Control Group

Based on the polygon curve above, it can be known that the mode is smaller than the median, and the median is smaller than mean $\mathrm{Mo}<\mathrm{Md}<\mathrm{M}(16.04<16.39<16.57)$ so that the curve formed is a positive squint curve. That is, the score obtained tends to be low. Based on the analysis of the data carried out can be presented the results of the normality test distribution data of students' history experiment group and control group in Table 1.

Table 1. Normality Test Results Distribution Data Score Student Learning Results History

\begin{tabular}{lccc}
\hline $\begin{array}{l}\text { Affective Learning } \\
\text { Outcomes Data Group }\end{array}$ & X2 & $\begin{array}{c}\text { Critical Value with 5\% } \\
\text { Significance }\end{array}$ & Description \\
\hline Experimental Group & 7.079 & 8.835 & Normal \\
Control Group & 5.68 & 6.79 & Normal \\
\hline
\end{tabular}

Based on the results of calculations using the Chi-Squared formula, it was obtained that the student learning score data of the history of the experiment group and the control group distributed normally.

In this study, homogeneity tests were conducted on the variance between experimental groups and control groups. The test used is an F test with homogeneous data criteria if $F_{\text {calculates }}<F_{\text {table. Recapitulation of variance homogeneity test results between }}$ experimental groups and control groups is presented in Table 2.

Table 2. Homogeneity Test Results Distribution Data Score Student Learning Results History

\begin{tabular}{lcccc}
\hline Data Source & Variance & $\begin{array}{c}F \\
\text { Count }\end{array}$ & $\begin{array}{c}\mathrm{F}_{\text {table with Significance }} \\
\text { Level of 5\% }\end{array}$ & Status \\
\hline $\begin{array}{l}\text { Experimental Group } \\
\text { Control Group }\end{array}$ & 18.57 & 1.31 & 3.14 & Homogeneous \\
\hline
\end{tabular}

Based on Table 2, it can be known that variance of student learning data history of experimental group and homogeneous control group. The test was conducted using independent sample t-test (not colluding) with polled variance formula to prove the hypothesis submitted. The results of the t-test analysis are presented in Table 3. 
Table 3. Summary of t-Test Calculation Results.

\begin{tabular}{lcccccc}
\hline Group & $\mathrm{N}$ & Mean $(X)$ & $\mathrm{S} 2$ & $\mathrm{t}_{\text {cout }}$ & $\begin{array}{c}\mathrm{T}_{\text {tab }}(\mathrm{t} . \mathrm{s} \\
5 \%)\end{array}$ & Conclusion \\
\hline Experiment & 23 & 19.36 & 20.25 & 53.82 & 2.000 & $\mathrm{t}_{\text {cout }}>\mathrm{t}_{\text {table }} \mathrm{H}_{0 \text { rejected }}$ \\
Control & 20 & 14.57 & 12.84 & & & \\
\hline
\end{tabular}

Table 3 shows that $t_{\text {cout }}$ is higher than $t_{\text {table }}\left(t_{\text {cout }}>t_{\text {table), }}\right.$ so $H_{0}$ is rejected, and $H_{1}$ is accepted. Thus, it can be interpreted that there are significant differences between the group of students who studied using the VCT learning model in grade XI IPA 3 and the group that was taught with conventional learning in grade XI IPA 1 students.

\section{Discussion}

Based on the research conducted, there were differences in average student learning outcomes in the experiment and control groups. However, students' learning outcomes in the history of the experimental group were higher than those of the control group. The difference shows that the VCT learning model affects students' learning outcomes in grade XI SMAN 9 Bogor city in historical learning.

VCT learning models have advantages compared to other learning models; among others, values and morals can be understood and instilled in the student; the teacher can easily convey the meaning/message of value/morals on the content of the subject matter. Moreover, the student can clarify and assess the quality of moral value in him and the value that exists in others; the potential of the student mainly develops the potential attitude can be formed easily, and; give an idea of moral values that are acceptable and guide and motivate to live decent and high moral (Khairunisa, 2017; Taniredja et al., 2012).

The creativity of a history teacher in managing the classroom by practicing and developing an active, creative learning model and instilling values and character in students should be something we should appreciate. Teachers try to give the best for their students for the sake of achieving the expected goals. The achievement of the intended goal is the student's learning outcomes. In this case, improving the quality of education will be drawn on the quality of learning that leads to high student learning outcomes. Therefore, in order to avoid low student learning outcomes, the VCT learning model can affect high student learning outcomes that will give rise to the tendency to behave according to the value of learning targets such as caring, hard work, discipline, honesty, and open (Rai, 2013; Sulistyawati \& Zuchdi, 2016). Learning outcomes will also influence students' positive attitudes and interests towards learning. Learning outcomes can be expressed in the form of achievements. If the achievement is good, then it will affect the students' values and attitudes. For that, the teacher must set a good example, help, guide, and encourage his students in character formation.

VCT learning process can involve and motivate students to be interested, interested, and positive by using models with theoretical components, motivation, and emotions to geoscience learning (Kraft et al., 2011). Then there is research from Worrell et al. (2002), which reveals that sports teachers should set examples of good attitudes to have a good responsibility and motivation towards physical learning (sports). This is the right step to improve students' learning outcomes optimally. In addition, research in the Journal of Physical Education states that teachers need to position themselves as the main object of physical education teaching, to help students learn to value their own and others' contributions, to be more independent, to adapt peer teaching to the needs of themselves and others, and to think about ability in terms of contribution (Casey \& Fernandez-rio, 2019). Thus, VCT learning provides positive student learning outcomes covering cognitive, affective, and psychomotor spheres. 


\section{Conclusion}

The conclusion is that there is a significant difference in historical learning outcomes between the group of students who studied with the online-based VCT learning model and the group of students who studied with conventional learning models. Value Clarification Technique learning model affects improving students' learning outcomes in historical learning. This learning model values and promotes positive values in students, generate interest and interest in historical learning and changes the paradigm of students to be actively involved in exploring meaningful knowledge and understanding.

\section{References}

Aman, A. (2013). Pengembangan Model Evaluasi Program Pembelajaran Sejarah Di Sma. Jurnal Penelitian Dan Evaluasi Pendidikan, 16(2), 437-456. https://doi.org/10.21831/pep.v16i2.1126.

Byford, J., Lennon, S., \& Russell, W. B. (2009). Teaching Controversial Issues in the Social Studies: A Research Study of High School Teachers. The Clearing House: A Journal of Educational Strategies, Issues, and Ideas, 82(4), 165-170. https://doi.org/10.3200/tchs.82.4.165-170.

Casey, A., \& Fernandez-rio, J. (2019). Pendidikan Sejarah Untuk Memperkuat Pendidikan Karakter. Paramita: Historical Studies Journal, 22(1). https://doi.org/10.1080/07303084.2019.1559671.

Casinillo, L. F., \& Aure, M. R. K. L. (2018). ). Econometric evidence on academic performance in basic calculus of science, technology, engineering and mathematics (STEM) senior high students. Journal of Educational and Human Resource Development, 6, 238-249.

Doležalová, J. (2015). Competencies of Teachers and Student Teachers for the Development of Reading Literacy. Procedia - Social and Behavioral Sciences, 171, 519-525. https://doi.org/10.1016/j.sbspro.2015.01.156.

Jumardi, J. (2017). Peranan Pelajaran Sejarah Dalam Pengembangan Karakter Siswa melalui Pembelajaran Berbasis Nilai Sejarah Lokal di SMA Negeri 65 Jakarta Barat. Jurnal Pendidikan Sejarah, 6(2), 70-80. https://doi.org/10.21009/JPS.062.08.

Khairunisa, N. (2017). The Implementation of Value Clarification Technique (VCT) Learning Model to Improve Social Care Character in Social Science Learning. International Journal Pedagogy of Social Studies, 2(1), 153. https://doi.org/10.17509/ijposs.v2i1.8689.

Kraft, V. D. H., Srogi, L., Husman, J., Semken, S., \& Fuhrman, M. (2011). Engaging students to learn through the affective domain: A new framework for teaching in the geosciences. Journal of Geoscience Education, 59(2), 71-84. https://doi.org/10.5408/1.3543934a.

Mannan, M. N., \& Sopyan, A. (2005). Pengembangan Perangkat Pembelajaran Berbasis Kearifan Lokal untuk Menembangkan Karakter Positif Siswa SD. Jurnal Inovasi Dan Pembelajaran Fisika, 2(2), 141-146.

Mosconi, J., \& Emmett, J. (2003). Effects of a Values Clarification Curriculum on High SchoolStudents' Definitions of Success. Professional School Counseling, 7(2), 68-78. https://www.jstor.org/stable/42732546?seq=1.

Munawar, A., \& Suryadi, A. (2019). Pengembangan Media Pembelajaran Sejarah Indonesia Berbasis Videoscribe Materi Kerajaan Islam Di Jawa Kelas X Tahun Ajaran 2018/2019 Di SMA Negeri 3 Salatiga. Indonesian Journal of History Education, 7(2), 
174-184. https://doi.org/10.15294/ijhe.v7i2.36436.

Rai, D. R. (2013). Comparative Effectiveness of Value Clarification and Role Playing Value Development Models for Selected Values for Primary School Students. IOSR Journal Of Humanities And Social Science, 19(1), 28-34. https://doi.org/10.9790/083719112834.

Ramadhan, A. N., \& Soenarto, S. (2015). Pengaruh Persepsi Siswa Terhadap Faktor-Faktor Yang Mempengaruhi Prestasi Belajar Teori Kejuruan Siswa Smk. Jurnal Pendidikan Vokasi, 5(3), 297-312. https://doi.org/10.21831/jpv.v5i3.6485.

Reichardt, C. S., \& Mark, M. M. (2015). Non-equivalent Group Designs. In International Encyclopedia of the Social \& Behavioral Sciences: Second Edition. https://doi.org/10.1016/B978-0-08-097086-8.44039-0.

Sanjaya. (2017). Pembelajaran dan Desaind Sistem Pembelajaran. Kencana Perenda Media Group.

Sardiman, S. (2015). Menakar Posisi Sejarah Indonesia pada Kurikulum 2013. ISTORIA: Jurnal Pendidikan Dan Ilmu Sejarah, https://doi.org/10.21831/istoria.v11i2.7555.

Sayono, J. (2013). Pembelajaran Sejarah Di Sekolah: Dari Pragmatis Ke Idealis. Jurnal Sejarah Dan Budaya, 7(1), 109-123. http://journal.um.ac.id/index.php/sejarah-danbudaya/article/view/4733.

Siregar, E., Mulyono, M., Asmin, A., Mukhtar, M., \& Firdaus, M. (2019). Differences in Problem Solving Capabilities among Students Given a Problem-Based Learning Blended Learning with Conventional Learning. American Journal of Educational Research, 7(11), 755-763. https://doi.org/10.12691/education-7-11-3.

Sulistyawati, N., \& Zuchdi, D. (2016). Implementasi Teknik Pembelajaran Kolaboratif Dengan Variasi Media Untuk Peningkatan Hasil Belajar di SMPN 2 Kalijambe. Harmoni Sosial: Jurnal Pendidikan IPS, 3(1), 50-61. https://doi.org/10.21831/hsjpi.v3i1.9694.

Suryani, N., Sejarah, P. P., \& Maret, U. S. (2013). Pengembangan Model Internalisasi Nilai Karakter Dalam Pembelajaran Sejarah Melalui Model Value Clarification Technique. Paramita - Historical Studies Journal, 23(2). https://doi.org/10.15294/paramita.v23i2.2674.

Sutaryanto, S. (2016). Penerapan Model Value Clarification Technique (Vct) Berbantuan Film Dokumenter Dalam Menanamkan Nilai Nasionalisme Dan Meningkatkan Hasil Belajar Pada Siswa Sekolah Dasar. Premiere Educandum: Jurnal Pendidikan Dasar Dan Pembelajaran, 5(2), 237-252. https://doi.org/10.25273/pe.v5i02.287.

Taniredja, T., Afandi, M., \& Faridli, E. M. (2012). The appropriate Pancasila education contents to implant lofty values for Indonesian students. Educare: International Journal for Educational Studies, 5(1). https://doi.org/10.2121/edu-ijes.v5i1.269.

Ulhaq, Z., Nuriah, T., \& Winarsih, M. (2017). Pembelajaran Sejarah Berbasis Kurikulum 2013 di SMA Kotamadya Jakarta Timur. Jurnal Pendidikan Sejarah.

Wijayanti, A. T. (2015). Implementasi Pendekatan Values Clarivication Technique (Vct) dalam Pembelajaran IPS di Sekolah Dasar. SOCIA: Jurnal Ilmu-Ilmu Sosial, 10(1). https://doi.org/10.21831/socia.v10i1.5343.

Worrell, V., Evans-Fletcher, C., \& Kovar, S. (2002). Assessing the Cognitive and Affective Progress of Children. Journal of Physical Education, Recreation \& Dance, 73(7), 29 34. https://doi.org/10.1080/07303084.2002.10607844. 